\title{
Constraints of the vegetable farmers affecting their entrepreneurial behaviour in Kerala
}

\author{
James Mohan Devadas and K.N. Ushadevi
}

Received : 11.08.2018; Revised : 11.09.2018; Accepted : 19.09.2018

\begin{abstract}
A study on the constraints faced by the vegetable farmers on their entrepreneurial behaviour (EB) in Kerala was conducted confining to the three district of Kerala viz., Palakkad, Thrissur and Ernakulam which representing the central zone. 450 commercial vegetable farmers were selected purposively from five agro ecological zones of central Kerala for the study. From each agro ecological zone one block which had maximum area under vegetable cultivation was selected proportionately. Out of the 450 sample size fifty percentage of farmers represent VFPCK farmers and other fifty percentage represent ordinary farmers. To analyse the constraints which affect the entrepreneurial behaviour of vegetable farmers following variables were selected i.e., production constraints, constraints in technology factor, organisational support constraints, economic constraints, financial constraints, social constraints and marketing constraints. Among the seven listed constraints marketing constraints affect them the most followed by production constraints, economic constraints and constraints in technology factor. Organisational support constraints were least bothered as far as Kerala is concerned because most of the farmers were aware about the services provided from various institutions and most of the institutions try to keep in touch with farmers too. Even though VFPCK famers were more relaxed with respect to the marketing channels, both the category of farmers considered marketing constraints as more serious than any other constraints. Both categories of farmers felt all constraints in the same order of intensity.
\end{abstract}

KEY WORDS : Constraints, Vegetable farmers, Entrepreneurial behaviour, Production constraints, Constraints in technology factor, Organisational support constraints, Economic constraints, Financial constraints, Social constraints, Marketing constraints

How to cite this paper : Devadas, James Mohan and Ushadevi, K.N. (2018). Constraints of the vegetable farmers affecting their entrepreneurial behaviour in Kerala. Internat. J. Com. \& Bus. Manage, 11(2) : 137-142, DOI: 10.15740/HAS/IJCBM/11.2/137-142. Copyright@2018: Hind Agri-Horticultural Society.

\section{MEMBERS OF THE RESEARCH FORUM}

\section{Correspondence to:}

James Mohan Devadas, Department of Rural Marketing Management, College of Co-operation, Banking and Management, Kerala Agricultural University, Vellanikkara, Thrissur (Kerala) India E-mail: jamy777@gmail.com

\section{Authors' affiliations:}

K.N. Ushadevi, Department of Rural Marketing Management, College of Co-operation, Banking and Management, Kerala Agricultural University, Vellanikkara, Thrissur (Kerala) India 